\title{
ココア㠌取がヒト体表温に及ぼす影響
}

\author{
有山 愛 ${ }^{\S}$, 森 由佳*, 稲野美穂, 灘本知憲 \\ 滋賀県立大学人間文化学部生活栄養学科 \\ *株式会社宇治田原製茶場
}

\section{Effect of Cocoa on Human Body Surface Temperature}

\author{
Ai Ariyama ${ }^{\S}$, Yuka Mori*, Miho Inano and Tomonori Nadamoto \\ Department of Food Science and Nutrition, School of Human Culture, \\ University of Shiga Prefecture, 2500 Hassaka, Hikone, Shiga 522-8533 \\ * Ujitaharaseichajou Co., Ltd., Gounoguchi, Uzitahara, Tsuzuki, Kyoto 610-0281
}

\begin{abstract}
We investigated whether consumption of cocoa raises human body surface temperature. Healthy female student volunteers (age 18-24) were enrolled in this study. We measured their body surface temperature and peripheral blood flow in a stringently air-controlled room (temperature, $22 \pm 0.5^{\circ} \mathrm{C}$; humidity, $50 \pm 5 \%$ ). First, the effect of pure cocoa consumption at $60^{\circ} \mathrm{C}$ and $37^{\circ} \mathrm{C}$ was compared with that of soup consisting of the same nutritional composition and water. At $60^{\circ} \mathrm{C}$, pure cocoa tended to increase the peripheral body temperature at the wrist, ankle and tip of the foot, while at $37^{\circ} \mathrm{C}$ it tended to maintain the peripheral body temperature at the wrist. Next, defatted cocoa at $60^{\circ} \mathrm{C}$ was compared with control drink consisting of the same nutritional composition. Defatted cocoa increased the temperature at the forehead $(p$ $<0.05)$ and maintained the temperature at the finger tips $(p<0.05)$; this same tendency was also observed at the abdomen and waist. Using the same defatted cocoa and control drink samples, we examined the situation immediately before sleeping. Defatted cocoa increased the temperature at the wrist, ankle and tip of the foot $(p<0.05)$. Thus, cocoa consumption results in increasing or maintaining the human body surface temperature, while defatted cocoa consumption effects are especially remarkable.
\end{abstract}

(Received May 29, 2009 ; Accepted Sep. 4, 2009)

Keywords : cocoa, body surface temperature, coldness, human, blood flow

キーワード : ココア, 体表温, 冷え症, ヒト, 血流

冷え症とは「体の特定の部位だけが冷たく不快に感じら れる状態」のことである. 最も多いのが手足の冷えである が, 首や腰が冷える，低体温であるなどその症状は様々で あり，はっきりとした原因は分かっていない，冷え症の症 状は冬期に留まらず，夏期にも冷えを訴える者屯ある。現 代では若い女性だけでなく壮年男性にまで泠え症が見られ るようになって打り，冷え症患者は増加傾向にある1 ${ }^{1}$. 身近 な食品を摂取することで日常的に起こる冷えの改善ができ れば, 冷え症患者の QOL 向上につながるであろう. 香辛料 を中心に，いくつかの食品が冷えの改善に繋がるかむしれ ないことが示されてきている，例えばトゥガラシの発汗・ 温熱作用は，その有効成分がカプサイシンなどであること 屯含め, 広(知られている2 3). 著者らの過去の研究4) であ ショウガがヒト体表温上昇促進作用を示した。

干522-8533 滋賀県彦根市八坂町 2500

* $=610-0281$ 京都府綴喜郡宇治田原町郷之口

\&連絡先 (Corresponding author), f33aariyama@ec.usp.ac.jp
本報では香辛料以外の食品として，ココアに着目して実 験を行った。ココアがテオブロミンといわゆるカカオポリ フェノールを多く含み, これらの成分による血管拡張作 用56) などを通して冷え改善効果の可能性があるからであ る. 実際, ココアの体表温に対する影響については過去に 報告(例? がある。しかし，砂糖やミルクの入ったココア飲 料の効果を, コーヒ一や緑茶と比較しており, 栄養組成や エネルギー含量の違いによるとの疑念を拭えない，本報告 ではココアと栄養組成を揃えた対照飲料を比較し，実際に ヒトの体表温の低下抑制，または上昇促進作用がココアに あるか否かを検討した。

ココアは日常的に摄取されており, 市販品む多くあり, 手に入れやすい食品である.ココアの原料となるカカオ （Theobroma cacao）の歴史は紀元前 4000 年にまで遡り, 紀元前 2000 年頃から古代メキシコを中心に栽培が始まっ たとされている，学名の一部である「Theobroma（テオブ ロマ)」とはギリシャ語で “神様の食べ物”という意味で, 
古代メキシコでは，不老長寿薬として王侯貴族の間で珍重 されていた。当時はカカオをすり潰したものを食していた が，これがスペインを経てヨーロッパ全土に広がり，現在 のように世界中に人々に親しまれているチョコレートやコ コアに変化を遂げた7).

また，コレステロール低下作用や血圧低下作用 ${ }^{899)}$ など の優れた効果が報告されており，ココアの持つ様々な効果 について研究が進められている。近年の報告では, ココア の老化抑制効果 ${ }^{10)}$ ，抗動脈硬化作用 ${ }^{11)}$, 生活習慣病 - 生活

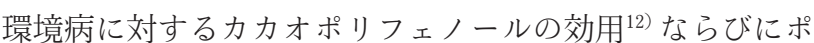
リフェノールによるストレス制御の可能性 ${ }^{13)}$ などがある.

今回の実験では，体表温变化を主な指標として，ココア 摂取がヒト体表温に与える影響の検討を目的とした。

\section{実 験 方 法}

\section{1. 被験者亡摂取飲料}

18-24 歳の健常な女子学生を対象として実験を行った. 本試験はヘルシンキ宣言の精神に則り, 滋賀県立大学倫理 審査委員会の承認を受けると共に，被験者にはあらかじめ 研究の趣旨および試験内容を充分説明し，承諾を得た。

(1) 実験 1

21-22 歳の 6 名を対象とした。摂取試料は，試験飲料と してピュアココア $8 \mathrm{~g}$ を，栄養組成を揃えた対照飲料とし て中華風スープ，さらに同量（150 ml）の湯を用いた 3 種 とした。飲料の構成材料と栄養組成を Table 1 に示す。試 験飲料, 対照飲料と屯 $150 \mathrm{ml}$ の浄水に溶かし, 全ての飲料 を $60^{\circ} \mathrm{C}$ で摂取に供した。

(2) 実験 2

18-22 歳の 10 名を対象とした。試験飲料，対照飲料は, 実験 1 と同じピュアココア，栄養組成を揃えた中華風スー プとした。両飲料とも， $37^{\circ} \mathrm{C}$ で摂取に供した。

\section{(3) 実験 3}

21-23 歳の 6 名を対象とした。試験飲料は脱脂ココア （超臨界二酸化炭素抽出によって，脂肪分を $1 \%$ 未満に除 去したココアパウダー） $8 \mathrm{~g}$ とした。 ゼラチン，グラニュー 糖などで栄養組成を揃えた対照飲料を調製した。脱脂ココ アの苦味を抑えるため，両飲料に同量のスキムミルクを加 えた．両飲料の構成材料と栄養組成を Table 2 に示す．両 飲料とも， $60^{\circ} \mathrm{C}$ で摂取に供した。

(4) 実験 4

21-24 歳の 10 名を対象とした．試験飲料，対照飲料は実 験 3 に同じとした。

なお実験 2〜4においては, 飲料摂取後, 飲料の風味を口 腔内に残さないよう, 飲料と同温度の浄水 $30 \mathrm{~g}$ を摂取さ せた。

2. 摂取飲料の栄養組成とテオブロミン, ポリフェノー ル含量測定方法

試験飲料および対照飲料の栄養組成とエネルギー含量は 五訂食品成分表より算出した.

試験飲料中のテオブロミン，ポリフェノール含量測定 は，試料に試料の 5 倍容の $\mathrm{n}$-ヘキサンを加え，30 分間振 とうしたのち，遠心分離し，乃過した。さらに振とう，遠 心分離，万過操作を 2 回繰り返した残渣を風乾し，脱脂試 料とした. 脱脂試料 $0.5 \mathrm{~g}$ に $50 \%$ メタノールを加え超音波 分散し，還流抽出，遠心分離した。その上清を $50 \%$ メ夕 ノールにて，100 ml に定容し，遠心分離したのち，ろ過し たものを抽出液とした。

テオブロミン含量は抽出液を HPLC にて分析した.

ポリフェノール含量は, 抽出液をフォーリンーチオカルト 法 ${ }^{14)}$ に準じて測定し，エピカテキン相当量として算出した.

\section{3. 測定指標}

身体各部の体表温度は，皮膚温測定装置（BDT100 用温 度センサー，バイオリサーチセンター(株)）を用いて 1 秒

Table 1 Ingredients of testing drink and control drink for Exp. 1 and Exp. 2

\begin{tabular}{lllll}
\hline \hline & \multicolumn{2}{c}{ Testing drink (pure cocoa) } & \multicolumn{2}{c}{ Control drink } \\
\hline constituent material & water & $150 \mathrm{ml}$ & water & $150 \mathrm{ml}$ \\
& pure cocoa $^{\mathrm{a})}$ & $8.0 \mathrm{~g}$ & chicken soup powder $^{\mathrm{b})}$ & $3.1 \mathrm{~g}$ \\
& & & colza oil $^{\mathrm{c})}$ & $1.8 \mathrm{~g}$ \\
& & & dried albumen & \\
& & & & $1.45 \mathrm{~g}$
\end{tabular}

calories

$27.2 \mathrm{kcal}$

protein

fat

carbohydrate

theobromine

polyphenol

$184.8 \mathrm{mg}$

$351.2 \mathrm{mg}$
$27.9 \mathrm{kcal}$

$1.7 \mathrm{~g}$

$1.9 \mathrm{~g}$

$0.8 \mathrm{~g}$

a) pure cocoa (MORINAGA \& CO., LTD.), ${ }^{\text {b) }}$ gara soup (YOUKI FOOD CO., LTD), ${ }^{c}$ healthy light (The Nisshin OilliO Group, Ltd.), ${ }^{\text {d) }}$ kansouranpaku(TOHMEI FOODS CO., LTD.) 
Table 2 Ingredients of testing drink and control drink for Exp. 3 and Exp. 4

\begin{tabular}{|c|c|c|c|c|}
\hline & Testing drink (defat & ted cocoa) & Control drink & \\
\hline constituent material & $\begin{array}{l}\text { water } \\
\text { defatted cocoa } \\
\text { skim milk }\end{array}$ & $\begin{array}{l}150 \mathrm{ml} \\
8.0 \mathrm{~g} \\
18.0 \mathrm{~g}\end{array}$ & $\begin{array}{l}\text { water } \\
\text { gelatin }^{\mathrm{c})} \\
\text { colza oil }^{\mathrm{d})} \\
\text { granulated sugar }^{\mathrm{e})} \\
\text { skim milk }^{\mathrm{b})}\end{array}$ & $\begin{array}{l}150 \mathrm{ml} \\
2.60 \mathrm{~g} \\
0.13 \mathrm{~g} \\
1.36 \mathrm{~g} \\
18.0 \mathrm{~g}\end{array}$ \\
\hline calories & $85.4 \mathrm{kcal}$ & & $80.0 \mathrm{kcal}$ & \\
\hline protein & & & & \\
\hline fat & & & & \\
\hline carbohydrate & & & & \\
\hline theobromine & $207.2 \mathrm{mg}$ & & & \\
\hline polyphenol & $236.0 \mathrm{mg}$ & & & \\
\hline
\end{tabular}

毎に自動測定した．実験 1 では測定時間 3 分おきに 1 分間 の值を, 実験 2〜 4 では測定時間 1 分ごとに值を平均し, 各 時間での測定值とした。血流量の測定には, 半導体レー ザー血流装置（ALF21D，（株)ADVANCE）を用いて 1 秒 毎に自動測定した。測定時間 1 分ごとに值を平均し，各時 間での測定值とした。

各実験における，測定箇所を以下に示す。

実験 1 ; 額中央 - 首筋 - 左手首 - 左手薬指 - 左足首 - 左 足人差し指の体表温, 左手薬指血流

実験 2 ; 額中央 - 首筋 - 左手首 - 左手薬指 - 左足首の体 表温，左手首血流

実験 3 ; 額中央・首筋 - 左脇 - 腹 $($ 臍下) - 左手首 $\cdot$ 左 手薬指 $\cdot$ 左足首 $\cdot$ 左足中指の体表温, 左手中 指・左足中指の血流

実験 4 ; 左手首 - 左手薬指 - 左足首 - 左足中指の体表 温, 左足薬指の血流

\section{4. 実験環境}

室温 $22.0 \pm 0.5^{\circ} \mathrm{C}$, 湿度 $50 \pm 5 \%$ (加熱気化式加湿機, HV-T50CX, シャープ(株)）に設定した恒温・恒湿室（プ レハブ恒温室 東洋紡エンジニアリング(株)) 内で行った.

\section{5. 測定プロトコル}

実験はクロスオーバーで行った．体温の日内变動を考慮 に入れ，実験 4 を除き 9〜11 時の間に 2 名ずっ行った. 実 験 4 は $17 \sim 19$ 時に 1 名ずつ実験を行った. 被験者ごとに それぞれの試験について 1 日以上ウォッシュアウト期間を 設け，同時刻に実験を開始した。実験 1 3 は座位で, 実験 4 は簡易ベッドで, 背もたれを使って約 60 度に上半身を起 こし, 足を伸ばした仰臥位で行った。 また, 女性の月経周 期における体温变化を考慮して, 体温の安定する月経終了 日から 2 週間以内を実験日とした。
実験日前日は，激しい運動や暴飲暴食を避け，薬，トウ ガラシなど香辛料の多い食品やカフェイン飲料などの刺激 物の飲食を控えさせた. 実験日当日, 実験 1 〜 では実験開 始 2 時間以上前に起床，朝食を欠食とし，測定開始前の 2 時間以内は摂水も禁止した。 実験 4 では実験日当日, 朝食, 昼食は摂取させたが，上記前日の条件を守らせた。なお， 測定開始前の 2 時間以内は絶飲，絶食とした。ささらに，日 中は長ズボン，靴下，スニーカーの統一した服装で過ごす ように指示した，測定時の服装の違いによる体温への影響 を除くため，被験者には測定時用の専用服（Tシャツ，白 衣，トレーニングズボン，ソックス）を着用させた。実験 前に気分，体調を確認するためのアンケートを行った，実 験のプロトコルを Fig. 1 に示す.一定の温度に設定された 前室（実験 $1: 22^{\circ} \mathrm{C}$, 実験 $2 \sim 4: 25^{\circ} \mathrm{C}$ ) で 20 分程度実験環 境に順応させ，その間に実験専用服の着用と事前アンケー 卜を行った。 その後, 測定室に入り装置装着を含め 20 分程 度安静を保ったのち, 測定を開始した. 測定開始 15 分後に 3 分以内で試験飲料を摂取させた。 飲料摂取時には皮膚温 測定装置を装着していない手のみ，使用を許可した．飲料 摂取開始時を 0 分とし, 実験 1 ・ 2 は 48 分間, 実験 3 は 68 分間測定を行った。実験 4 は入室後のプロトコルは実験 1 〜3 と同様であるが，就寝時を想定し，飲料摂取後被験者 を素足にし，その後布団をかけた。測定時間は，飲料摂取 開始から 75 分とした。

実験中は安静を保たせ，必要以上の動作を禁止した。眠 気対策に，測定中は実験 1 では絵本等を読む事を許可し， 実験 2〜4においては, 無音の DVD を鑑賞させ, 会話を禁 止した.

実験時期は, 実験 1 は 10 月, 実験 2 は 11 月から 2 月, 実験 3 は 6 月, 実験 4 は 12 月から 1 月に行った。 
Experiment 1 3
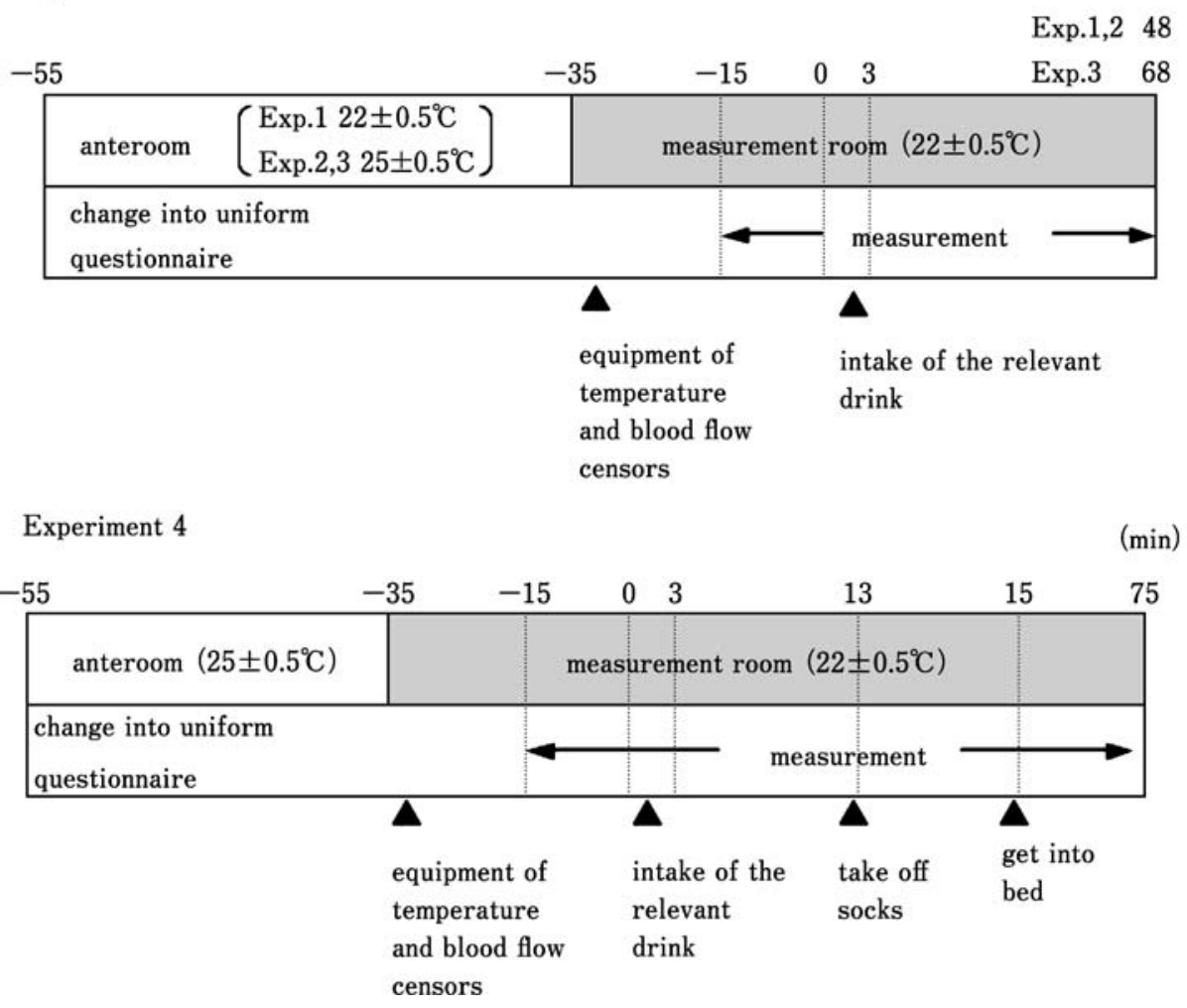

Fig. 1 Testing protocol

\section{6. 統計処理}

測定值はすべて平均值士SEM で表した，有意差検定は， Fisher の PLSD による多重比較検定, contrasts による多 重比較検定, paired-t-test, 二元配置分散分析 (Two-way repeated ANOVA）で行った。解析ソフトはStat View for Macintosh (Ver.5.0, SAS Institute Inc.) および, Super ANOVA (Ver.1.1, Abacus Concepts Inc.) を使用 した。いずれの場合も危険率 $5 \%$ 未満を有意水準とした。 なお，危険率 $10 \%$ 未満についてもр值をグラフ上に記載 した.

\section{実 験 結 果}

\section{1. 体表温・血流の変化}

(1) 実験 1

$60^{\circ} \mathrm{C}$ のピュアココア，栄養組成を揃えたスープ，湯を摂 取した後, 身体各部体表温の 48 分間の平均值を, 摂取前温 度からの变化量として, Fig. 2 に示す. ココアはスープと 水に比べ，末梢部位において体表温上昇促進傾向を示し た。しかしながら，手首・足指先におけるココアとスープ 間 $(p<0.1)$, 足首におけるココアと湯間 $(p<0.1)$ の相違 を含め，いずれの場合も有意な差ではなかった，各部位の 体表温の経時变化を見ると, 足首において有意な差が認め られた（Fig. 3). 足首では，特に飲料摂取後期間の後半か ら，ココアは他の二飲料との温度差が大きくなり，その差
は有意であった $(p<0.01)$.また，手指先では体表温に有意 な差が認められなかったが，血流量は摂取前 15 分間の平 均血流量と摂取後 48 分間の平均血流量の比較において

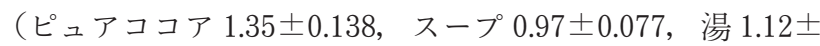
0.147), ココアはスープに比べて有意に $(p<0.05$ by Fisher's PLSD）血流促進作用を示した。

(2) 実験 2

飲料温度が体温に影響しない条件として，摂取温度を $37^{\circ} \mathrm{C}$ とたピュアココア摂取後の平均温度変化を, 実験 1 と同様の対照スープと比較した結果を Fig. 4 に示す。ココ アは対照飲料に比べ，上半身の末梢部位（手首，手指先） において冷え抑制傾向を示した。 しかし，手首においても $(p<0.1)$, 手の指先においても統計的に有意な差は認めら れなかった．特に手指先では個人間のばらつきが大きかっ た。なお，手首血流量（摂取前 15 分間の平均血流量と摂取 後 48 分間の平均血流量の比較 : ピュアココア $0.97 \pm 0.030$, スープ 0.98土0.058）にも有意な差がみられなかった。

(3) 実験 3

試験飲料として脱脂ココア $\left(60^{\circ} \mathrm{C}\right)$, 対照飲料として栄養 組成を揃えた飲料とした。脱脂ココア飲料を飲みやすくす るため，同量のスキムミルクを両飲料に加えた。摂取後 68 分間の平均体表温变化を Fig. 5 に示す.ココアは対照飲料 に比べ, 上半身末梢部 (手首, 手指先) に加え, 額, 腹, 腰において体表温低下抑制作用がみられた。額，手指先に 


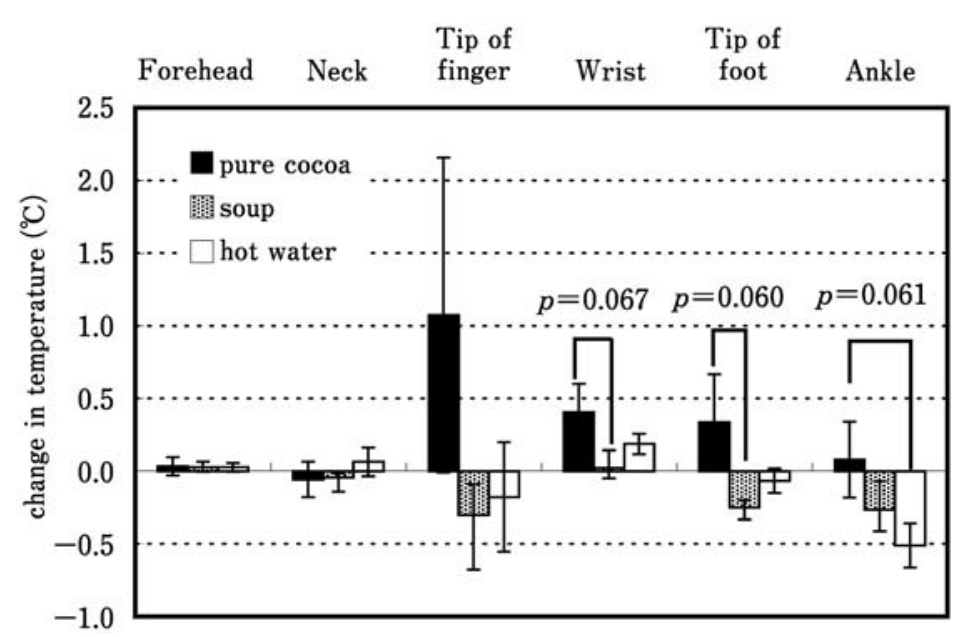

Fig. 2 Change in the body surface temperature after consuming pure cocoa, soup or hot water The average change in body surface temperature after consuming pure cocoa $\left(60^{\circ} \mathrm{C}\right)$, soup $\left(60^{\circ} \mathrm{C}\right)$ or hot water $\left(60^{\circ} \mathrm{C}\right)$ is shown. Values are expressed as the difference between the average values during 48 minutes after consuming and those before consumption $(-9,-6,-3,0 \mathrm{~min})$. Mean \pm SEM, $n=6, p$ values by Fisher's PLSD.

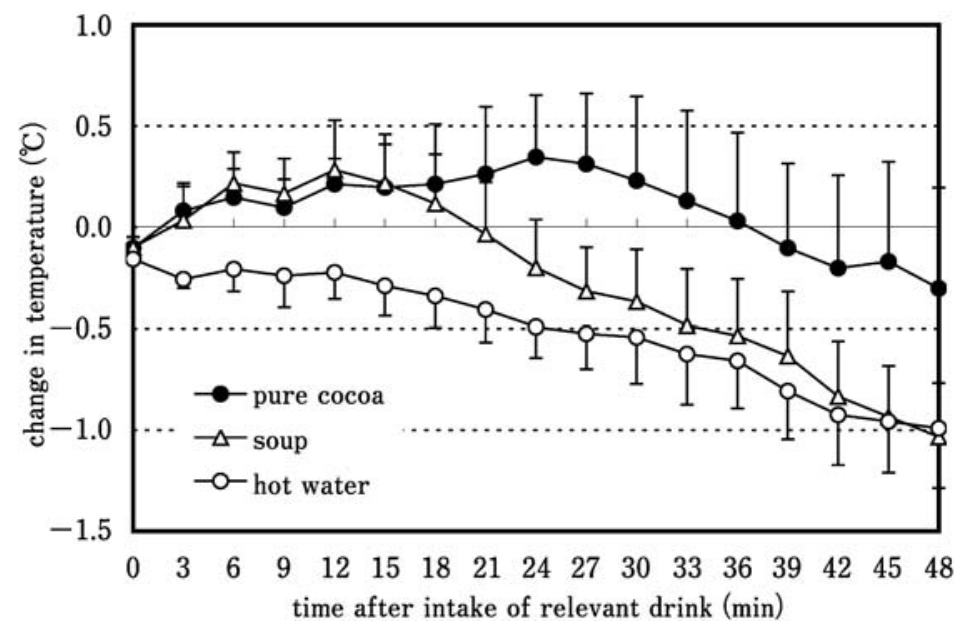

Fig. 3 Time-course change in the ankle surface temperature after consuming pure cocoa, soup or hot water Temperature fluctuation of ankle surface temperature after consuming pure cocoa $\left(60^{\circ} \mathrm{C}\right)$, soup $\left(60^{\circ} \mathrm{C}\right)$ or hot water $\left(60^{\circ} \mathrm{C}\right)$ is shown. Values are expressed as the difference from the average before consumption $(-9,-6,-3,0 \mathrm{~min})$.

Mean \pm SEM, $n=6$, Cocoa vs. Soup : $p<0.01$ by contrasts.

おいては有意に体表温低下を抑制し $(p<0.05)$, お腹, 腰に おいては体表温低下抑制傾向がみられた $(p<0.1)$. 足指先 は個人差が大きく，ココアの効果は認められなかった。一 方, 手指先, 足指先の血流量は体表温変化を反映した結果 となったが有意な違いは観察されなかった（㨫取前 15 分 間の平均血流量之摂取後 68 分間の平均血流量の比較 : 手 指先 脱脂ココア $0.97 \pm 0.044$, 対照飲料 $0.92 \pm 0.027$, 足指 先 脱脂ココア $1.08 \pm 0.062$, 対照飲料 $1.40 \pm 0.310)$.

手指先の体表温の経時変化を Fig. 6 に示す. 摂取後の時 間経過に伴って, ココア摂取は対照飲料と比較して手指先 の冷えを抑制し, 有意な交互効果 $(p<0.05)$ が認められた。
実験 3 では体表温測定部位として, 腹, 腰部を加えたが, その経時変化を Fig. 7 に示す. 飲料の如何に関わらず体表 温は上昇したが，手指先の場合之同様，摂取後期間の後半 に温度差は大きくなり，両群の経時変化には交互効果 $($ 腹； $p<0.05$, 腰 $; p<0.0001 ）$ が認好わた.

(4) 実験 4

就寝前を想定した状況での, $60^{\circ} \mathrm{C}$ 脱脂ココア摂取後の手 足抹消部の平均体表温变化を Fig. 8 に示す。仰臥位で手足 とも布団の中に入れたため, いずれの部位む飲料の如何に 関わらず体表温は上昇した。 ココアは対照飲料に比へ，上 半身末梢部位に加え, 下半身末梢部位でむ体表温上昇促進 


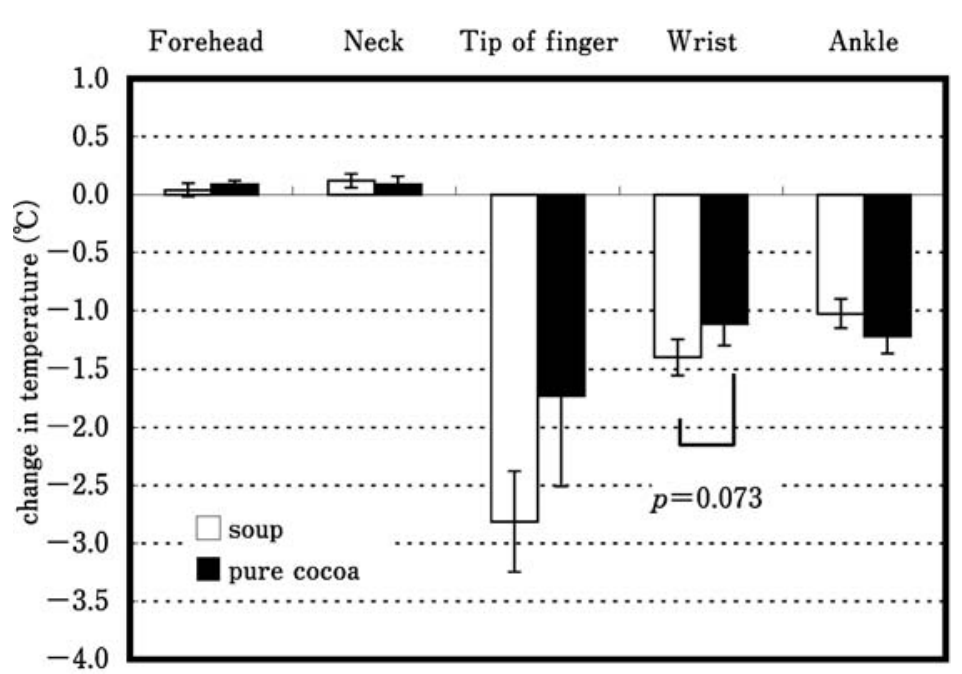

Fig. 4 Change in the body surface temperature after consuming pure cocoa or soup

The average change in body surface temperature after consuming pure cocoa $\left(37^{\circ} \mathrm{C}\right)$ or soup $\left(37^{\circ} \mathrm{C}\right)$ is shown. Values are expressed as the difference from the average before consumption $(-15 \sim 0 \mathrm{~min})$. Mean \pm SEM, $n=10, p$ values by paired $t$-test.

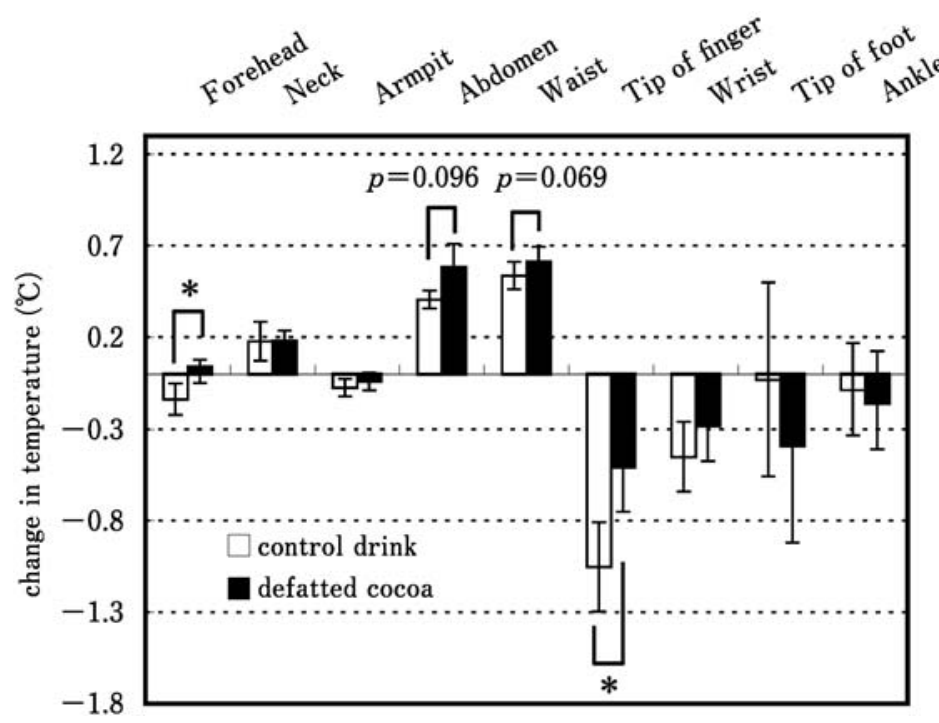

Fig. 5 Change in the body surface temperature after consuming defatted cocoa or control drink The average change in body surface temperature after consuming defatted cocoa $\left(60^{\circ} \mathrm{C}\right)$ or control drink $\left(60^{\circ} \mathrm{C}\right)$ is shown. Values are expressed as the difference between the average values during 68 minutes after consuming and those before consumption $(-15 \sim 0 \mathrm{~min})$.

Mean $\pm \operatorname{SEM}, n=6$, $p$ values by paired $t$-test. ${ }^{*} p<0.05$.

作用を示した。特に，手首，足首，足指先における，体表 温上昇促進作用は有意であった $(p<0.05)$. 足指血流量 (摂 取前 15 分間の平均血流量と摂取後 75 分間の平均血流量の 比較 : 脱脂ココア $2.81 \pm 0.941$, 対照飲料 $1.33 \pm 0.103 ）$ に有 意な差は見られなかった。

差が最屯顕著に現れた足指先体表温の経時変化を Fig. 9 に示す．飲料摂取後 13 分に一時的に温度低下が見られる が，これは靴下を脱ぐ動作が入ったことによる．布団をか けた 15 分後から, 脱脂ココアは対照飲料に比べ急速に足
指先温度を上昇させ，対照飲料との間に有意な交互効果 $(p<0.0001)$ が認められた.

考察

「冷え症」は現代病ともいわ机, 暮らしの中では無視でき ないつらいものである。その原因については血流の低下や 代謝の低下が考えられるが，科学的究明はいまだ充分とは 言えない. 冷え症は, 特に女性に多く, QOL に与える影響 は大きい，著者らが女子学生 97 名に行ったアンケート ${ }^{15)}$ 


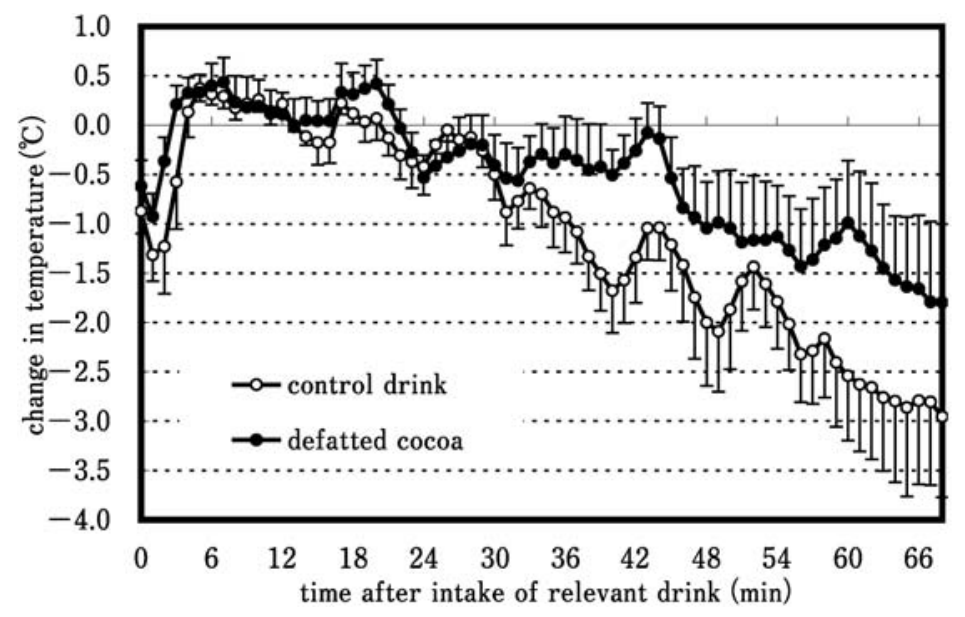

Fig. 6 Time-course change in the tip of finger surface temperature after consuming defatted cocoa or control drink Temperature fluctuation of tip of finger surface temperature after consuming defatted cocoa $\left(60^{\circ} \mathrm{C}\right)$ or control drink $\left(60^{\circ} \mathrm{C}\right)$ is shown. Values are expressed as the difference from the average before consumption $(-15 \sim 0 \mathrm{~min})$.

Mean \pm SEM, $n=6$, Cocoa vs. Control Drink $p<0.05$ by Two-way repeated ANOVA.

によれば，約 70\%が冷え症と自覚しており，しかもこの割 合は寺澤らの冷え症判断基準 ${ }^{16)}$ による結果とほぼ一致し た. 冷えを訴える部位は手足あるいはその指先が中心であ り，多くの若い女性が抹消体表温の低下に悩まされている ことが窺われる。

我々は, 実験環境として一定の温度環境を設定し, 食品 摂取による体表温の变化を見ることで，冷え症の改善に有 効な食品因子を検索することをテーマに研究を行ってき た. 冷え改善作用検証のための体表温測定にはサーモグラ フが使われることも多い17). 本実験では温度センサーを用 いたが，同時に複数部位の温度を連続的に測定・記録でき ることが特長といえる。 また，手足指を冷水に浸漬し，引 き上げた後の回復の程度を見る自律神経機能検査法として の水水浸漬試験 ${ }^{18)}$ の応用 ${ }^{17)}$ や, 冷水浸漬法 ${ }^{19)}$ がよく用いら れている.これらは局部のみの急速な冷えを伴う反応であ り, 全身に及ぶ冬期の冷えや夏期の冷房など日常生活上に 即した状況ではない。本報では測定指標として皮膚温測定 装置および半導体レーザー血流計を用い, 日常起こりう るゆるやかな冷えの状況を想定した。

栄養組成を揃えた対照飲料を用いた理由は，食事誘発性 体熱産生（DIT）による影響を抑える事である。食事摄取 後, DIT によるエネルギー消費増加量は, 食事の質と量に より大きく異なり, 摂取エネルギー量に対する比率で示す と, タンパク質の場合は約 $30 \%$ と特に高く, 糖質約 6\%, 脂質では約 $4 \%$ と報告されている ${ }^{20)}$. 今回の実験ではこの ような作用の影響をできるだけ除くため, 試験飲料と三大 栄養素の組成を揃えた飲料を調製し，対照飲料とした。

実験 1 では市販のピュアココアを試験飲料とし, 栄養組 成をこれと揃えた中華風スープ，さらに湯を対照飲料とし， 摂取に供した。 ピュアココアは末梢部位で体表温上昇促進
傾向を示し，その作用は足首において最も顕著であった.

実験 2 では飲料温度を $37^{\circ} \mathrm{C}$ とた。これは, 体温に影響 を与えないような飲料温度でもココアの温作用が現れるの かを見るためである。湯を除き, 試験飲料, 対照飲料とあ 実験 1 と同様とした。 その結果，手首，手指先で対照飲料 と比較して有意な差ではなかったものの，体表温低下抑制 傾向が見られた。

以上の結果よりピュアココアは抹消部位を中心に体表温 上昇促進作用むしくは体表温低下抑制作用を示す可能性が 示唆された。 また, 過去の報告例7) で考慮されていなかっ た, 栄養組成やエネルギー含量の違いによる作用ではなく, ピュアココアによる作用である事が示された。 しかし，飲 料温度 $37^{\circ} \mathrm{C}$ でも体表温低下抑制効果が期待できるが, $60^{\circ} \mathrm{C}$ の結果と比較すると明快ではなかった.

一方脱脂ココアを試料とした実験 3 では，ココアの効果 がよりクリアとなった。用いた脱脂ココアは, ココアパウ ダー（脂肪分 10-20\% 程度）を脱脂し，脂肪分を 1\%以下 にした市販品である。脱脂ココアパウダーを使用する事に より, 実験 1,2 で供試試料に比較的多く含まれていた脂質 （脂肪分 $23 \%$ エネルギー含量の 6 割以上を占める）のココ アと対照飲料での質的な違いを除けること，さらに温作用 が現れた場合，ココアの脂質成分がその因子であることを 除外することができる. 摂取物の脱脂ココアはピュアココ アに比べると苦味が強いため, スキムミルクをべヒクルと して用いることで呈味を改善した. ミルクを加えることに より, カカオポリフェノールの吸収は有為に促進されない ことはJ.B. Keogh らによって示されている21). また実験 1, 2 の結果で, ココアの温作用が摂取後期間の後期に, よ り顕著に示された事から, 測定時間を 68 分まで延長した。 Fig. $5 \cdot 6$ の結果より, 脱脂ココアは手指先などの上半 

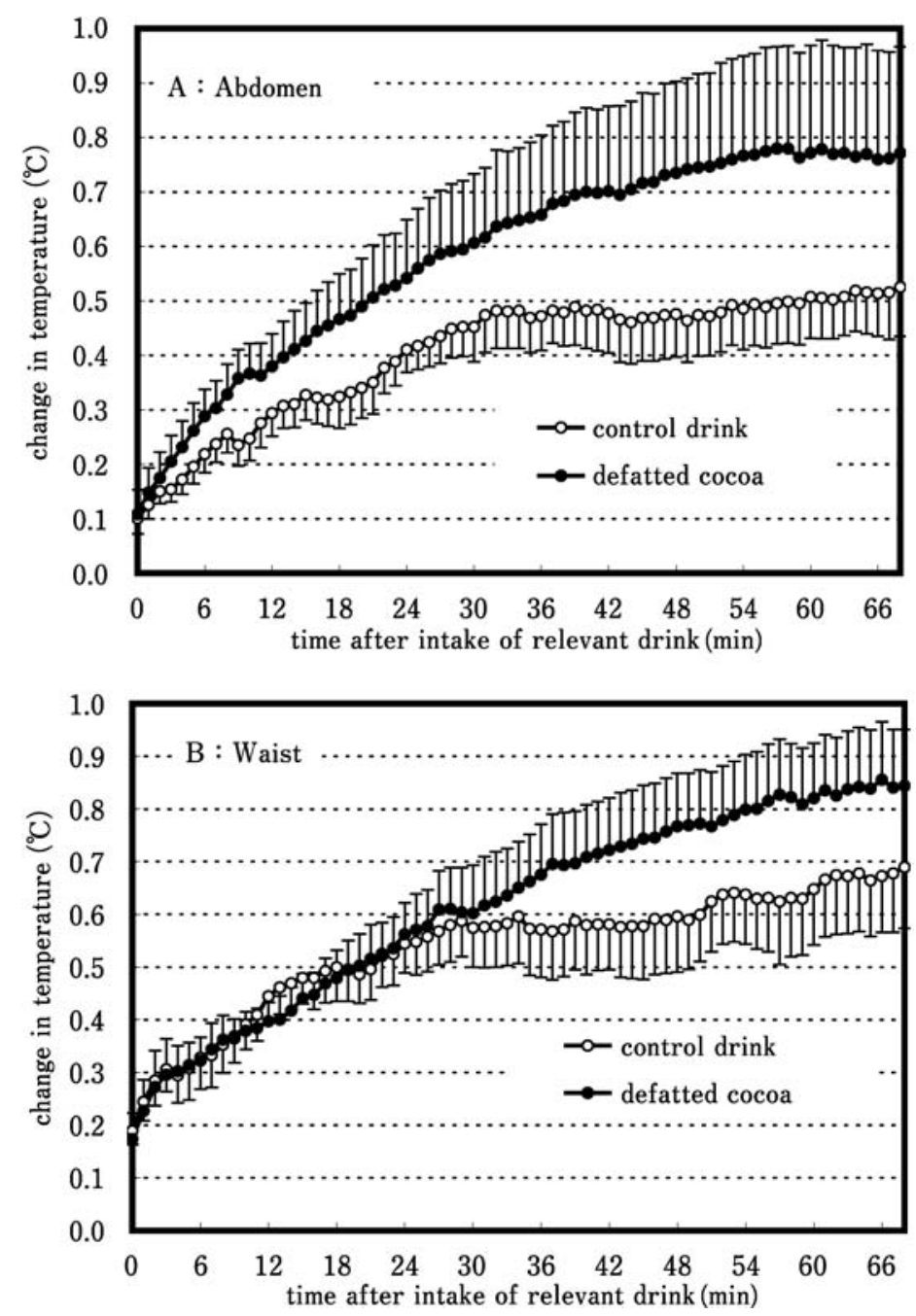

Fig. 7 Time-course change in the abdomen (A) and waist (B) surface temperature after consuming defatted cocoa or control drink

Temperature fluctuation of tip of finger surface temperature after consuming defatted cocoa $\left(60^{\circ} \mathrm{C}\right)$ or control drink $\left(60^{\circ} \mathrm{C}\right)$ is shown. Values are expressed as the difference from the average before consumption $(-15 \sim 0$ min).

Mean \pm SEM, $n=6$, Cocoa vs. Control Drink $p<0.05$ by Two-way repeated ANOVA.

身の末梢部位において有意な体表温低下抑制効果を示した。 また末梢部位に加え，額，腹，腰においても有意な体表温 上昇促進作用を示した。

以上の実験 1 3 3 りココアパウダーの温作用が再現性 よく確認された。対照飲料はココア飲料と三大栄養素を揃 えていることから，ココアの作用が DIT による可能性は 低く, また実験 3 より体表温上昇促進作用がココアの脂質 ではない可能性が高まったため，ココア特有の成分による ことが示唆された。

ココア特有の成分としては, カカオポリフェノールやテ オブロミンが挙げられる，テオブロミンは，古くは動脈硬 化症, 末梢血管疾患, 狭心症, 高血圧症などの治療薬とし て用いられていた歴史がある。 また，最近の報告では，テ オブロミンが咳止め薬として有効であるとの報告がなされ
ている ${ }^{22)}$. 我が国では，標準品のテオブロミンを用いた， 動物やヒトへの経口試験の報告は皆無に等しく, 世界的に 見ても乏しいのが現状である。しかし，同じキサンチン類 で，コーヒーの主要成分であるカフェインに関しては，ヒ トへの経口試験が広く行われている。比野らのヒト対象 試験においては，カフェインが自律神経系に作用するとい う報告があり ${ }^{23)}$, Bracco らのヒト試験では，カフェイン入 りコーヒーの摂取がカフェインレスコーヒーの摂取に比 べ，体熱産生が高まったという報告あある ${ }^{24)}$.このことか らも，類似の構造をとっているテオブロミンは同様の効果 が期待できる.

カカオポリフェノールに関する報告は，血小板活性抑 制 ${ }^{25)}$, 抗動脈硬化作用, 胃潰瘍予防 ${ }^{26)}$, 発がん予防作用 ${ }^{27)}$ など多岐にわたる，血流改善の効果も多数報告されてい 


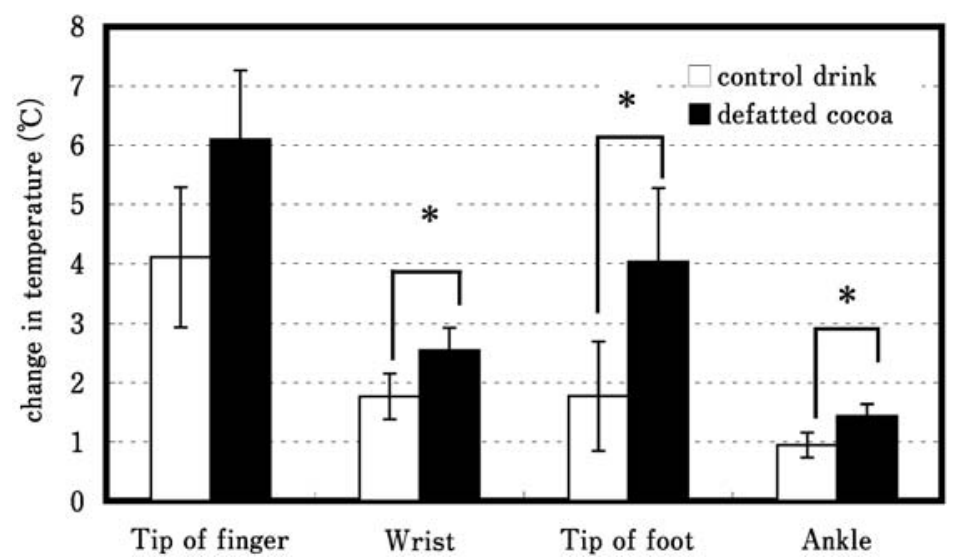

Fig. 8 Change in the body surface temperature after consuming defatted cocoa or control drink The average change in body surface temperature after consuming defatted cocoa $\left(60^{\circ} \mathrm{C}\right)$ or control drink $\left(60^{\circ} \mathrm{C}\right)$ is shown. Values are expressed as the difference between the average values during 72 minutes after consuming and those before consumption $(-15 \sim 0 \mathrm{~min})$. Mean \pm SEM, $n=10, p$ values by paired $t$-test. ${ }^{*} p<0.05$

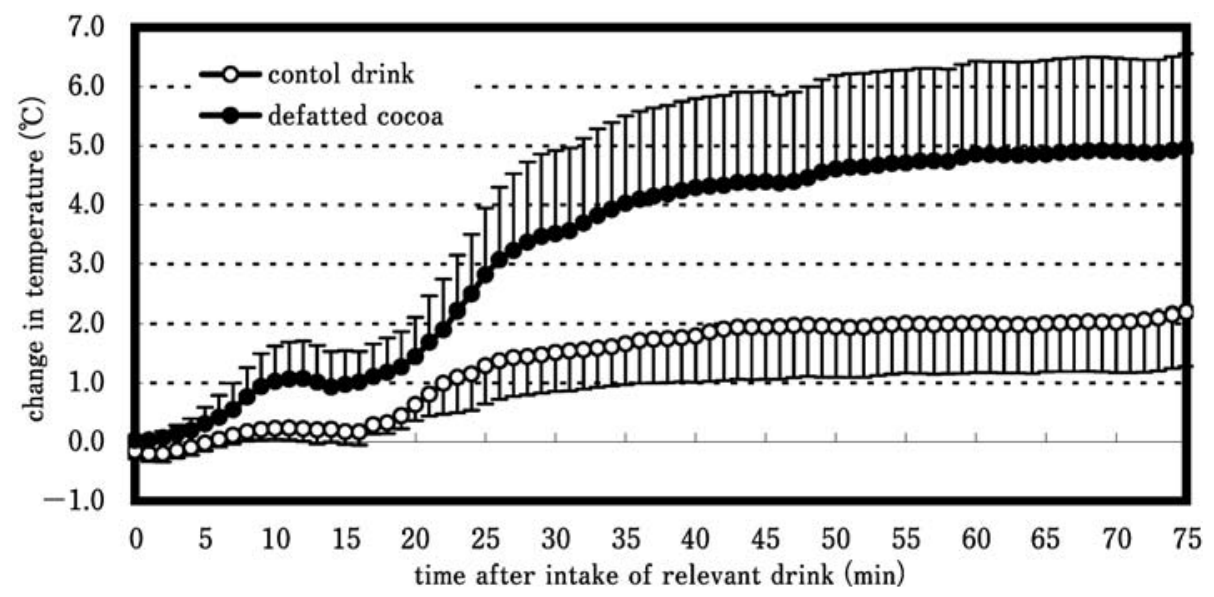

Fig. 9 Time-course change in the tip of foot surface temperature after consuming defatted cocoa or control drink Temperature fluctuation of tip of finger surface temperature after consuming defatted cocoa $\left(60^{\circ} \mathrm{C}\right)$ or control drink $\left(60^{\circ} \mathrm{C}\right)$ is shown. Values are expressed as the difference from the average before consumption $(-15 \sim 0 \mathrm{~min})$.

Mean \pm SEM, $n=10$, Defatted Cocoa vs. Control Drink $p<0.05$ by Two-way repeated ANOVA.

る. Helmut らは, ヒトに高フラバノール $(176 \mathrm{mg})$ のココ アを摂取させると，低フラバノール（10 mg 以下）のココ アを摂取させた場合と比べて，血管が拡張したと報告して いる5).また, Hagen ら屯, $1 \mathrm{mg} / \mathrm{kg}$ (body wight) のエ ピカテキンを含むココアをヒトに摃取させたところ，血管 拡張効果がみられたとしている6 ${ }^{6)}$.

テオブロミンもエピカテキンも吸収速度が速く, 摂取後 およそ 2 時間で血漿中濃度はピークを迎える ${ }^{28)}$. 実験 $1 \sim 3$ では摂取後 48-68 分を測定しているが，摂取後の後半でそ の効果は顕著にみられる。これら，テオブロミンとエピ カテキンの吸収速度を考慮すると, 説明ができる.

しかし, カカオポリフェノールに関する報告には, 注意 が必要である. Kelly は, Grassi らがチョコレート摂取に
よりインスリン感受性の向上と血圧低下を報告しており， それらの作用はチョコレートに含まれるフラボノール類 に8) としているが，実際そのサンプル中にはテオブロミン あ含まれており, その存在は決して無視できないと主張し ている ${ }^{29)}$. カカオポリフェノールの効果だと報告されてい る試験で用いられた試料中にはテオブロミンが存在する場 合があり，その力価については十分に検討が行われている のか疑問が残る。

冷え症者の多くが末梢部位における冷えの影響により, 入眠の妨げられていると感じていることから，実験 4 では 就寝前を想定した状況での実験を行った。実験 3 において も，時間経過に伴い，体表温上昇促進作用が顕著となった ことから，測定時間を 75 分まで延長した。 さらに実験 1 
3 では, 抹消部位の体表温は最終的に低下していく状況で の試験であったが，就寝時という抹消体温が上昇する状況 での実験ということも，実験 1～3 との相違となる.

「ヒトの体表温」は個人差が大きく, これを測定指標とす ることは一般的に非常に困難である. 東は, 季節に対する 外郭体温変動の個人差が大きいのが女子の特徴であり, 女 子の方が強く季節の影響を受けるとしている ${ }^{30)}$. そこでさ らに, 被験者に日中の服装を指定し, 着衣による下半身の 温度差を可能な限り減らすようにした。

Fig. 8 の結果より, 上半身末梢部位, 下半身末梢部位之 もに, 体表温上昇促進作用が示された. 実験 1 ～3 の結果と 比較し, 特に下半身末梢部位においてより顕著な体表温上 昇促進作用が示された。これは, 実験時の姿勢が実験 $1 \sim 3$ は座位であるのに対し, 実験 4 は足を伸ばした姿勢である ことと，布団を掛けることによる影響だと考えられる。

就寝前状況における, 末梢部位の体表温上昇促進効果が 示されたことで, 就寝前のココア摂取が冷え症患者の入眠 促進効果が期待される.

全実験を通し，ココア摂取がヒト体表温に有意な温作用 を示す部位は確定できなかった，被験者の個体内差や， 個々の被験者の個人間の差など, ヒトを対象として実験を しているゆえの影響が考えられる.さらに, 体表温を指標 としているために, 実験日の外気の影響屯予想され, 短時 間の拘束では取り除けない要因も考えられる.

測定指標として体表温と血流量を用いたが，体表温の上 昇と血流量の増加が必ずしも一致しない結果となった。 $22^{\circ} \mathrm{C}$ のおだやかな環境温下では, 体表温の上昇は抹消血管 の拡張・収縮作用を反映した結果と考えられるが，本実験 で用いた血流計のハード面の感度限界や測定部位など使用 条件が原因となり, 結果的に体表温の方が感度高く变化を 捉えたと考えられる.

ピュアココア，脱脂ココア摄取によりヒト体表温手首， 手指先等上半身末梢部位を中心に体表温低下抑制, または 上昇促進作用を示した. その効果は脱脂ココアにおいてよ り顕著に示された．脱脂ココアがより有効であった理由は 不明であるが以下のような可能性は考えられる. 試験飲料 であるココアと PFC 含量組成を揃えた対照飲料を作成し ているが，含量以外の要因については考慮されていない. そのため, ピュアココアと対照飲料では脂質の質の違いが 排除されていないが，脱脂ココアを試料とすることで脂質 の質の違いによる効果が取り除けた事による可能性が考え られる. また，ココア中の温作用を示す成分の吸収速度を 考慮すると, 摂取後測定時間を実験 $3 \cdot 4$ では実験 $1 \cdot 2$ よ り延長したことが要因かむしれない.さらに, 本実験で使 用した脱脂ココア中のテオブロミンおよびポリフェノール 含量は, Table 1, Table 2 に示すように, ピュアココアに 比べテオブロミン含量が多く, ポリフェノール含量は少な い. 試験飲料中のココア特有成分の含量の違いによる影響
あ考えられる.

今後は，ココア摂取がヒト体表温に温作用を示す有効成 分の特定とヒト体表温に温作用をむたらす他の食品の探索 が求められている. また, ココアの摂取タイミング, 摂取 形態による体表温への影響についても検討する必要がある.

\section{要約}

ココア摂取がヒト体表温を上昇させる影響を検討した。 被験者は健康な女子学生 (18-24 歳) とし, 体表温と抹消部 の血流量を測定指標とした。測定は $22^{\circ} \mathrm{C} \pm 0.5^{\circ} \mathrm{C}$, 湿度 $50 \% \pm 5 \%$ の恒温恒湿環境下，4通りの異なった条件で 行った. 結果は次の通りである.

(1) 実験 1 では, $60^{\circ} \mathrm{C}$ に加温されたピュアココア飲料に よる影響を，栄養組成を揃えた飲料，水と比較した。 ピュ アココアは手首, 足首, 足指先に, 体表温上昇傾向を示し た.

(2) 実験 2 では, $37^{\circ} \mathrm{C}$ に維持したピュアココア飲料と栄 養組成を揃えた飲料を比較した。 その結果, ピュアココア は手首に体表温維持傾向を示した。

（3）実験 3 では, $60^{\circ} \mathrm{C}$ 脱脂ココア飲料と栄養組成を揃え た飲料を比較した. 脱脂ココアは額における体表温上昇作 用 $(p<0.05)$ と手指における体表温維持作用 $(p<0.05)$ を 示した. また, 同様の傾向は, 腹と腰にも示された。

（4）実験 4 では, 実験 3 と同じ飲料を用いて就寝前状況 を想定した実験を行った，脱脂ココアは栄養組成を揃えた 飲料と比較し, 腰・足首・足指先で体表温上昇作用 $(p<$ 0.05）を示した.

以上の結果より, ココア摂取はヒト体表温上昇作用また は維持作用があることが示された，また，その効果は脱脂 ココアで特に顕著に観察された.

\section{文献}

1）本田利江, 平 陽一, 「専門医がやさしく教える冷え症」, 第 1 版 (PHP 研究所, 東京), pp. 10-23 (1998).

2) Szallasi, A. and Blumberg, P.M., Vanilloid (Capsaicin) Receptors and Mechanisms, Pharmacol Rev, The Ameri, 51 (2), 159-212 (1999).

3）岩井和夫, 渡辺達夫, 「トウガラシ 辛味の科学」, (幸書房, 東京), pp. 138-147 (2007).

4）藤沢史子, 灘本知憲, 伏木 亨, ショウガ摂取がヒト体表温 に及ぼす影響, 栄食誌, 58 (1)，3-9（2005).

5) Helmut, S., Tankred, S., Christian, H. and Malte, K., Cocoa polyphenols and inflammatory mediators, American Journal of Clinical Nutrition, 81, 304s-312s (2005).

6) Hagen, S., Christian, H., Jan, B. Petra, K., Keen, C.L., Hollenberg, N.K., Sies, H., Kwik-Uribe, C., Schmitz, H.H. and Kelm, M., (-)-Epicatechin mediates beneficial effects of flavanol-rich cocoa on vascular function in humans, Proceedings of the Nationsl Academy of Sciences of the United States of America, 103, 1024-1029 (2006).

7）亀井優徳, 吉川真理子, 橋爪秀一, ココアの冷え症改善効 果, 食の科学, 300, 4-13 (2003).

8) Grassi, D., Lippi, C., Necozione, S., Desideri, G. and Ferri, C., 
Short-term administration of dark chocolate is followed by a significant increase in insulin sensitivity and a decrease in blood pressure in healty persons. American Joumal of Clinical Nutrition, 81, 611-614 (2005).

9) Taubert, D., Roesen, R., Schömig, E., Effect of cocoa and tea intake on blood pressure, a meta-analysis. Archives of Internal Medicine, 167 (7), 626-634 (2007).

10）間藤 卓，ココアの老化抑制効果，食品工業，49（3），6975 (2006).

11）近藤和雄，カカオポリフェノールの抗動脈硬化作用，第 10 回チョコレート・ココア国際栄養シンポジゥム 2005 講演 集, pp. 30-31 (2005).

12）高野裕久, 生活習慣病・生活環境病に対するカカオポリ フェノールの効用, 食品工業, 50 (9), 57-64（2007）.

13）寺尾純二，ポリフェノールによるストレス制御の可能性一 抗うつ様活性を中心に一, 第 12 回チョコレート・ココア国 際栄養シンポジゥム 2007 講演集, pp. 5-8 (2007).

14）吉田隆志, 有井雅幸,「植物ポリフェノール含有素材の開 発」（株式会社シーエムシー出版, 東京) pp. 17-18 (2007).

15）灘本知憲, ココアによるヒト体表温の冷え改善効果, 第 13 回チョコレート・ココア国際栄養シンポジゥム 2008 講演 集, pp. 15-21 (2008).

16）寺澤捷年, 漢方医学に拈ける「冷え症」認識とその治療, 生 薬学雑誌, 41 (2), 85-96 (1987).

17）吉谷佳代, 南 利子, 宅見央子, 鏡 義昭, 白石浩荘, 米谷 俊, 冷えを訴える女性に及ぼす酵素処理ヘスペリジンの効 果, 日本栄養・食糧学会誌, 61（5）, 233-239（2008）.

18）日本自律神経学会, 「自律神経機能検查 第 3 版」(文光堂) pp. 236-239 (2000).

19) Hibino, G., Nadamoto, T., Fujisawa, F. and Fushiki, T., Regulation of the Peripheral Body Temperature by Foods: A temperature Decrease Induced by the Japanese Persimmon (kaki, Diospyros kaki), Biosci. Biotech. Biochem., 67 (1), 23-28 (2003).

20）河田照雄, 食品摂取と「食餌誘発性体熱産生」, 農化, 61, 1462-1465 (1987).
21) Keogh, J.B., McInerney, J. and Clifton, P.M., The Effect of Milk Protein on the Bioavailability of Cocoa Polyphenols, J. Food Sci., 72, S230-S233 (2007).

22) Usmani, O.S., Belvisi, M.G., Patel, H.J., Crispino, N., Birrell, M.A., Korbonits, M., Korbonits, D. and Barnes, PJ., Theobromine inhibits sensory nerve activation and cough, The FASEB Jounal, 19 (2), 231-233 (2005).

23) Hibino, G., Moritani, T., Kawada, T. and Fushiki, T., Caffeine Enhances Modulation of Parasympathetic Nerve Activity in Humans, Quantification Using Power Spectral Analysis, J. Nutr, 127, 1422-1427 (1997).

24) Bracco, D., Ferrarra, J.-M., Arnaud, M.J. and Jequier, E., Yves Schutz, Effects of caffeine on energy metabolism, heart rate, and methylxanthine metabolism in lean and obese women, The American journal of Physiology, 269 (4 Pt 1), E671-E678 (1995).

25) Rein, D., Paglieroni, T.G., Pearson, D.A., Wun, T., Schmitz, H.H., Gosselin, R. and Keen, C.L., Cocoa and Wine Polyphenols Modulate Platelet Activation and Function, J. Nutr., 130, 2120S-2126S (2000).

26）桜井光寛，鈍宝敬之，チョコレートとココアについて，香 料, 199, 85-94 (1998).

27）大澤俊彦, カカオポリフェノールの発癌予防作用, 第 3 回 チョコレート・ココア国際栄養シンポジゥム 1997 講演集, pp. 44-45 (1997).

28) Richelle, M., Tavazzi, I., Enslen, M. and Offord, E.A., Plasma kinetics in man of epicatechin from black chocolate, European Journal of Clinical Nutrition, 53, 22-26 (1999).

29) Caleb, J. Kelly, Effects of theobromine should be considered in future studies, Letter to the Editor, American Journal of Clinical Nutrition, 82 (2), 486-487 (2005).

30）東 隆暢，新しい測定法による女子の局所寒冷適応能の季 節変動, 龍谷大学社会科学研究年報, 34, 1-12 (2004).

(平成 21 年 5 月 29 日受付, 平成 21 年 9 月 4 日受理) 